\title{
Influence of counter electrode material during accelerated durability test of non-precious metal electrocatalysts in acidic medium
}

\author{
Jia Li a, Huiyuan Liu ${ }^{b}$, Yang Lüa, Xinwen Guo a, Yujiang Song a,* \\ a State Key Laboratory of Fine Chemicals, School of Chemical Engineering, Dalian University of Technology, Dalian 116024, Liaoning, China \\ b Dalian National Laboratories for Clean Energy, Dalian Institute of Chemical Physics, Chinese Academy of Sciences, Dalian 116023, Liaoning, China
}

\section{A R T I C L E I N F O}

\section{Article history:}

Received 30 January 2016

Accepted 7 May 2016

Published 5 July 2016

\section{Keywords:}

Non-precious metal electrocatalyst

Platinum counter electrode

Graphite counter electrode

Accelerated durability test

Acid medium

\begin{abstract}
A B S T R A C T
Significant progress has been made in the development of non-precious metal electrocatalysts (NPMEs) during the past decade. Correspondingly, there is an urgent demand for an appropriate measurement method to be established for the reliable evaluation of NPMEs. In this study, platinum and graphite counter electrodes were used to investigate the impact of counter electrode material on the accelerated durability testing (ADT) of NPMEs in acidic medium. Platinum used as the counter electrode in a traditional three-electrode electrochemical cell was found to dissolve in acidic medium and re-deposit on NPME coated on the working electrode during ADT. Such re-deposition causes the oxygen reduction reaction (ORR) performance of NPMEs to remarkably improve, and thus will seriously mislead our judgment of NPMEs if we are unaware of it. The phenomenon can be avoided using a graphite counter electrode.
\end{abstract}

(C) 2016, Dalian Institute of Chemical Physics, Chinese Academy of Sciences. Published by Elsevier B.V. All rights reserved.

\section{Introduction}

Proton exchange membrane fuel cells (PEMFCs) have become a focus of intensive research owing to their environmental friendliness and high energy conversion efficiency [1]. In PEMFCs, $\mathrm{H}_{2}$ fuel is electrochemically oxidized at the anode side and $\mathrm{O}_{2}$ is electrochemically reduced at the cathode side. The cathode reaction is a slow four-electron transfer reaction, which results in a high overpotential and thus high performance electrocatalysts are required to accelerate the oxygen reduction reaction (ORR). To date, platinum and platinum-based alloy nanoparticles dispersed on carbon supports have been dominantly employed as ORR electrocatalysts [2,3].
The ORR activity and durability of commercial $\mathrm{Pt} / \mathrm{C}$ and Pt-based electrocatalysts are routinely characterized by casting a thin layer of the electrocatalyst on a rotating disk electrode (RDE) and measuring its ORR performance in acidic medium in a three-electrode electrochemical cell, which is composed of a working electrode, a reference electrode, and a counter electrode [4-9]. It has been shown that the three-electrode electrochemical cell setup can be used to effectively evaluate the performance of electrocatalysts [10]. The performance of commercial Pt/C and Pt-based electrocatalysts is normally measured by cyclic voltammetry (CV) in $\mathrm{N}_{2}$-saturated electrolyte with ORR polarization on the RDE in the presence of $\mathrm{O}_{2}$. To assess the durability of an electrocatalyst, accelerated durabil-

\footnotetext{
* Corresponding author. Tel/Fax: +86-411-84986485; E-mail: yjsong@dlut.edu.cn This work was supported by the Fundamental Research Funds for the Central Universities (DUT15RC(3)001, DUT15ZD225), the Program for Liaoning Excellent Talents in University (LR2015014), the Liaoning BaiQianWan Talents Program (201519), and Dalian Excellent Young Scientific and Technological Talents (2015R006). DOI: 10.1016/S1872-2067(16)62454-3 | http://www.sciencedirect.com/science/journal/18722067 | Chin. J. Catal., Vol. 37, No. 7, July 2016
} 
ity testing (ADT) is carried out by potential cycling in the three-electrode system with CV and ORR measurements taken at certain cycle numbers to evaluate the degradation of the electrocatalyst in terms of electrochemical surface area (ECSA) and mass activity (MA) [5,6].

Commercial Pt/C electrocatalysts have been widely accepted as state-of-the-art electrocatalysts for ORR. However, platinum is scarce and expensive, so there is an urgent demand for the replacement of Pt-based electrocatalysts with high performance NPMEs. NPMEs have attracted much attention recently [11-16], and significant progress has been made in the investigation of novel synthetic approaches and the creation of NPME with high performance in acidic media [17-22]. For example, Feng and Müllen [20] reported a hierarchically porous NPME with an almost identical ORR half-wave potential to that of commercial $20 \mathrm{wt} \% \mathrm{Pt} / \mathrm{C}$ under alkaline conditions when the loading of both electrocatalysts was $0.1 \mathrm{mg} / \mathrm{cm}^{2}$. Liao and co-workers [23] synthesized a graphene-like NPME with a ORR half-wave potential only $60 \mathrm{mV}$ more negative than that of commercial $\mathrm{Pt} / \mathrm{C}$ in $0.1 \mathrm{~mol} / \mathrm{L} \mathrm{HClO}_{4}$. The electrochemical characterization of NPMEs has spontaneously inherited the characterization method used for commercial Pt/C, including as the same working electrode, reference electrode, and counter electrode in the three-electrode system, the same CV and ORR measurement sweep rate, and the same ADT conditions. However, the active sites and ORR reaction mechanism of NPMEs are more than likely to be different from those of commercial $\mathrm{Pt} / \mathrm{C}$, and therefore the effect of electrochemical characterization parameters on the evaluation of NPMEs should be paid special attention [24-26].

Herein, we focus on the effect of the counter electrode $[27,28]$ on the evaluation of NPMEs using the three-electrode cell in an acidic medium. For the three-electrode measurement system, almost all of the literature has used a platinum counter electrode when evaluating Pt-based electrocatalysts, but different counter electrodes in the case of NPMEs, such as platinum [29], graphite [19], and gold [30]. Only a few studies have addressed the selection of the counter electrode. In this study, we investigated the impact of counter electrode material on the performance of NPMEs during ADT in acidic medium. We found that the platinum counter electrode dissolved in acidic electrolyte and re-deposits on the NPME during ADT, which will seriously interfere with the measurement of the durability of NPMEs. This finding demonstrates that graphite counter electrodes should be used for ADT in acidic medium instead of platinum to allow the reliable judgment of NPME performance.

\section{Experimental}

\subsection{Materials}

Two types of electrocatalysts were used in the ORR performance tests. Commercial Pt/C (20 wt\% Pt on Vulcan XC-72) was purchased from Johnson Matthey, and a non-precious metal electrocatalyst was prepared in our lab. Nafion perfluorinated resin solution $(5 \mathrm{wt} \%$ in a mixture of lower aliphatic alcohols and water) was supplied by Sigma-Aldrich. All aque- ous solutions were prepared with ultrapure water (18.2 $\mathrm{M} \Omega \cdot \mathrm{cm}$ at $25^{\circ} \mathrm{C}$ ) from a Millipore water system (Synergy® UV, France).

\subsection{Electrode preparation}

A $5.0 \mathrm{~mm}$ diameter glassy carbon RDE (geometric area of $0.19625 \mathrm{~cm}^{2}$, Pine Research) was coated with a thin film of electrocatalyst. A slurry of NPME $(2 \mathrm{mg} / \mathrm{mL})$ was prepared by blending the electrocatalyst with water, ethanol, and Nafion solution $\left(V_{\text {water }}: V_{\text {ethanol }}: V_{\text {Nafion }}=1: 9: 0.06\right)$ under sonication in a water bath for $2 \mathrm{~min}$. The suspension was pipetted onto the RDE and evaporated in air, resulting in an electrocatalyst loading of $0.6 \mathrm{mg} / \mathrm{cm}^{2}$. For comparison, commercial $20 \mathrm{wt} \% \mathrm{Pt} / \mathrm{C}$ electrocatalyst ink $(1 \mathrm{mg} / \mathrm{mL})$ was prepared in a similar manner, and the $\mathrm{Pt} / \mathrm{C}$ loading on the resulting $\mathrm{RDE}$ was 20 $\mu \mathrm{g}_{\mathrm{Pt}} / \mathrm{cm}^{2}$.

\subsection{Electrochemical measurements}

All electrochemical measurements were carried out using an Autolab potentiostat/galvanostat (Echo Chemie BV Model PGSTAT-302N, The Netherlands) and a standard three-electrode electrochemical cell with the glassy carbon RDE as the working electrode, platinum mesh or graphite rod as the counter electrode, and a saturated calomel electrode (SCE) as the reference electrode, which was connected to the cell by a salt bridge (agar gel containing saturated $\mathrm{KNO}_{3}$ ). All potentials in this study are referenced to that of the reversible hydrogen electrode (RHE).

All of the electrochemical tests were carried out at $25^{\circ} \mathrm{C}$ in $\mathrm{N}_{2}$-saturated or $\mathrm{O}_{2}$-saturated aqueous $0.1 \mathrm{~mol} / \mathrm{L} \mathrm{HClO}_{4}$ solution. The CV curves of the electrocatalysts were recorded at a positive scan rate of $100 \mathrm{mV} / \mathrm{s}$. ORR polarization curves collected on the RDE were obtained at a rotation rate of $1600 \mathrm{rpm}$ and a scan rate of $10 \mathrm{mV} / \mathrm{s}$.

The electron transfer number of the electrocatalysts for ORR was determined using the Koutecky-Levich (K-L) equation:

$$
1 / I_{\mathrm{D}}=1 / I_{\mathrm{K}}+1 / B \omega^{1 / 2}
$$

where $I_{\mathrm{D}}$ is the measured current density at the glassy carbon $\mathrm{RDE}, I_{\mathrm{K}}$ is the kinetic current in amperes at a constant potential, $\omega$ is the electrode rotation speed ( $\mathrm{r} / \mathrm{min})$, and $B$ is the reciprocal of the slope, which can be determined from the slope of the $\mathrm{K}-\mathrm{L}$ plot using the Levich equation:

$$
B=0.62 n F A C_{0} D_{0}^{2 / 3} V^{-1 / 6}
$$

where $n$ is the number of electrons transferred per oxygen molecule, $F$ is the Faraday constant $(96485 \mathrm{C} / \mathrm{mol}), D_{0}$ is the diffusion coefficient of $\mathrm{O}_{2}\left(1.93 \times 10^{-5} \mathrm{~cm}^{2} / \mathrm{s}\right), C_{0}$ is the bulk concentration of $\mathrm{O}_{2}\left(1.26 \times 10^{-3} \mathrm{~mol} / \mathrm{cm}^{3}\right)$, and $v$ is the kinematic viscosity of the electrolyte $\left(0.01009 \mathrm{~cm}^{2} / \mathrm{s}\right)[21,31]$.

For ADT, the potential cycling was conducted between $0.6-1.2 \mathrm{~V}$ (vs RHE) at a scan rate of $100 \mathrm{mV} / \mathrm{s}$ in an $\mathrm{O}_{2}$-saturated acidic solution that provided a harsh degradation environment. CV curves and ORR polarization curves were collected at certain cycle numbers during the test to monitor the degradation of the electrocatalyst. 


\subsection{Physical characterization}

Transmission electron microscopy (TEM) images, energy dispersive X-ray spectra (EDS), and the elemental composition of the samples were investigated on a JEM-2100 microscope operated at $200 \mathrm{keV}$.

\section{Results and discussion}

The durability of an electrocatalyst is a key factor for its practical application in a PEMFC. However, evaluating this durability in operating PEMFCs requires a long time, up to over 10,000 hours. ADT was developed to shorten the test period by imposing artificially harsh conditions on the electrocatalyst system [32]. The potential cycling approach is a well-known method of testing the durability in a relatively short time, using RDEs in a three-electrode setup and simulation of the real operating conditions in PEMFCs [33]. The ADT of an electrocatalyst is normally conducted by consecutive potential cycling with suitable lower and upper potential limits. The degradation process is then macroscopically studied by measuring the loss of the ECSA and the MA of ORR over time. In this study, ADT was performed by cycling the electrocatalyst coated RDE be- tween 0.6 and $1.2 \mathrm{~V}$ vs RHE at a scan rate of $100 \mathrm{mV} / \mathrm{s}$ in $\mathrm{O}_{2}$-saturated $0.1 \mathrm{~mol} / \mathrm{L} \mathrm{HClO}_{4}$ solution at $25^{\circ} \mathrm{C}$, consistent with the conditions used in the literature [34-36]. Commercial Pt/C is commonly used as a baseline electrocatalyst for comparison in ADT. As shown in Fig. 1(a), the CV curve of commercial Pt/C continuously shrank with increasing potential cycle. In this case, the counter electrode was platinum. The calculated ECSA of the commercial Pt/C electrode rapidly decreased with increasing ADT cycle number, and after 2500 cycles the ECSA loss was $58.2 \%$, as shown in Fig. 1(a) and (b). Such a decrease in ECSA was caused by platinum nanoparticle agglomeration and dissolution and re-deposition during the ADT [37]. This was also responsible for the shift in the ORR half-wave potential toward lower potential with increasing ADT cycle number, as shown in Fig. 1c and d. The negatively shifted half-wave potential was $25 \mathrm{mV}$ after 2500 ADT cycles. This well-known ADT experiment with platinum counter electrode reveals the degradation of commercial $\mathrm{Pt} / \mathrm{C}$ well and is basically suitable for the evaluation of this kind of Pt-based electrocatalyst.

For the measurement of NPME in acidic medium, not much attention has been paid to the detailed test conditions of the ADT experiment. Therefore, in most of the literature the same test conditions have been chosen to perform the ADT of NPME
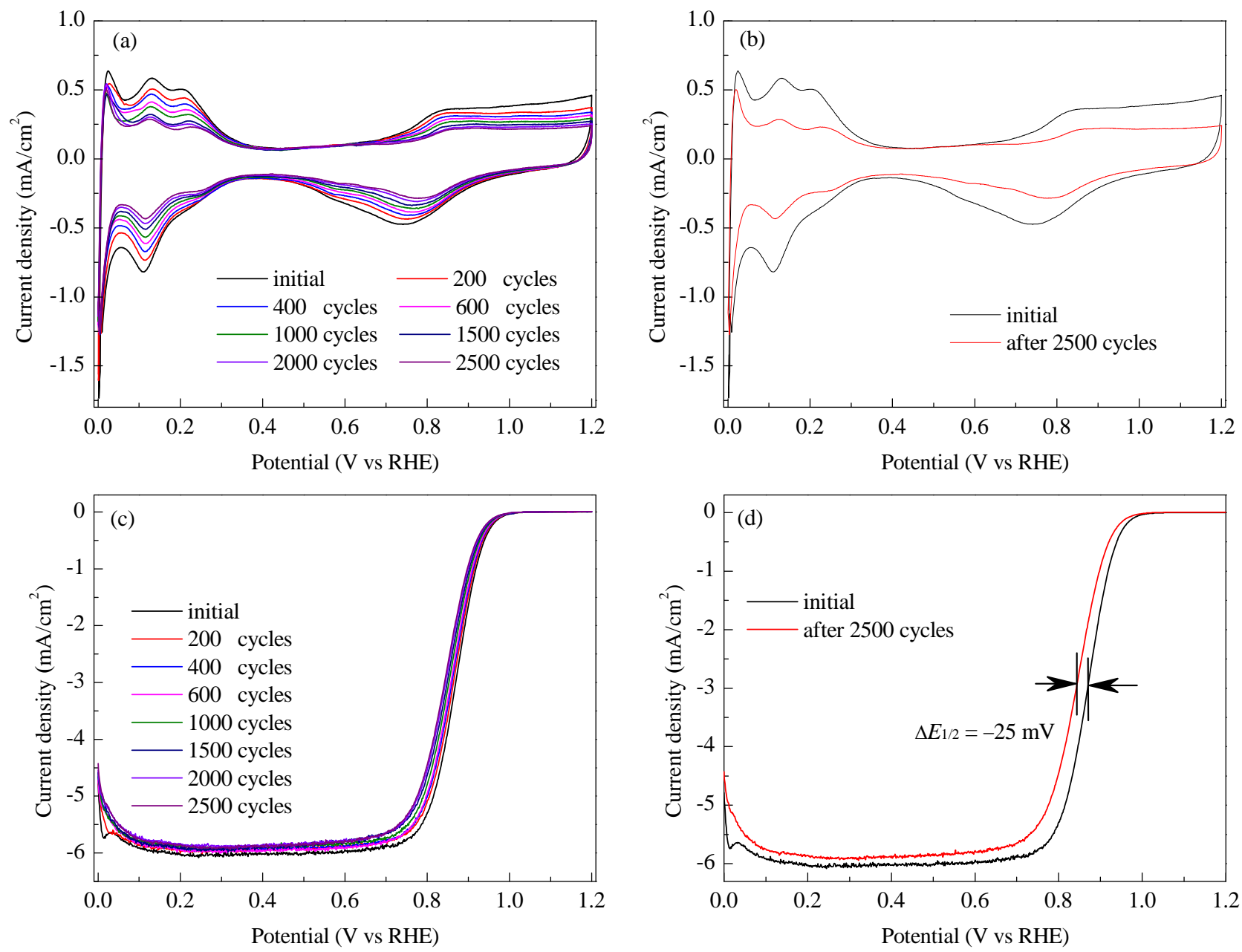

Fig. 1. CV curves $(\mathrm{a}, \mathrm{b})$ and ORR curves $(\mathrm{c}, \mathrm{d})$ of commercial $20 \mathrm{wt} \% \mathrm{Pt} / \mathrm{C}$ measured during ADT experiments. Potential cycling was carried out between 0.6 and $1.2 \mathrm{~V}$ (vs RHE) in $\mathrm{O}_{2}$-saturated $0.1 \mathrm{~mol} / \mathrm{L} \mathrm{HClO}_{4}$, with the scan rate of $100 \mathrm{mV} / \mathrm{s}$. 
$[17,21,29,38]$, including the employment of a platinum counter electrode. Superficially, it seems that the same test conditions might be appropriate for the ADT of NPME. In this study, the durability of our in-house-made NPME was detected by cycling the electrocatalyst coated RDE for 3000 cycles in the three-electrode system (Fig. 2). Unlike the commercial Pt/C, the double layer capacity of our NPME did not show any decrease and surprisingly increased a little bit after potential cycling, which may be caused by a better contact between the NPME and the electrolyte with time and/or enlarged surface area of the NPME by electrochemical corrosion. The ORR performance of the NPME showed different behavior as compared with commercial Pt/C during ADT. The half-wave potential negatively shifted about $19 \mathrm{mV}$ after 1500 ADT cycles, but more potential cycles obviously made the half-wave potential positively shift about $86 \mathrm{mV}$, which is $67 \mathrm{mV}$ higher than the initial one. This abnormal shift during ADT rendered the final ORR activity of the NPME is comparable with the final activity of commercial Pt/C after ADT in terms of half-wave potential (Fig. 3).

To elucidate the origin of the abnormal ORR performance during ADT, CV curves were collected in $\mathrm{O}_{2}$-saturated electrolyte (Fig. 4). The peak of oxide reduction was found to contin-

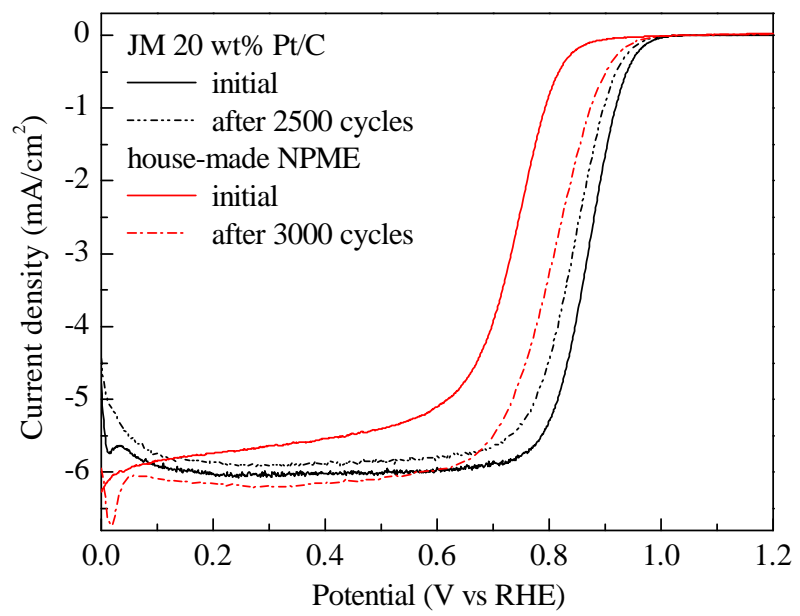

Fig. 3. ORR polarization curves of commercial Pt/C and in-house-made NPME before and after potential cycling in $\mathrm{O}_{2}$-saturated $0.1 \mathrm{~mol} / \mathrm{L}$ $\mathrm{HClO}_{4}$. Potential cycling was carried out from 0.6 to $1.2 \mathrm{~V}$ (vs RHE) at $100 \mathrm{mV} / \mathrm{s}$.

uously shift during the ADT, consistent with the change in the half-wave potential in the ORR polarization curves (Fig. 2(c)). The peak initially shifted to a lower potential, and then shifted
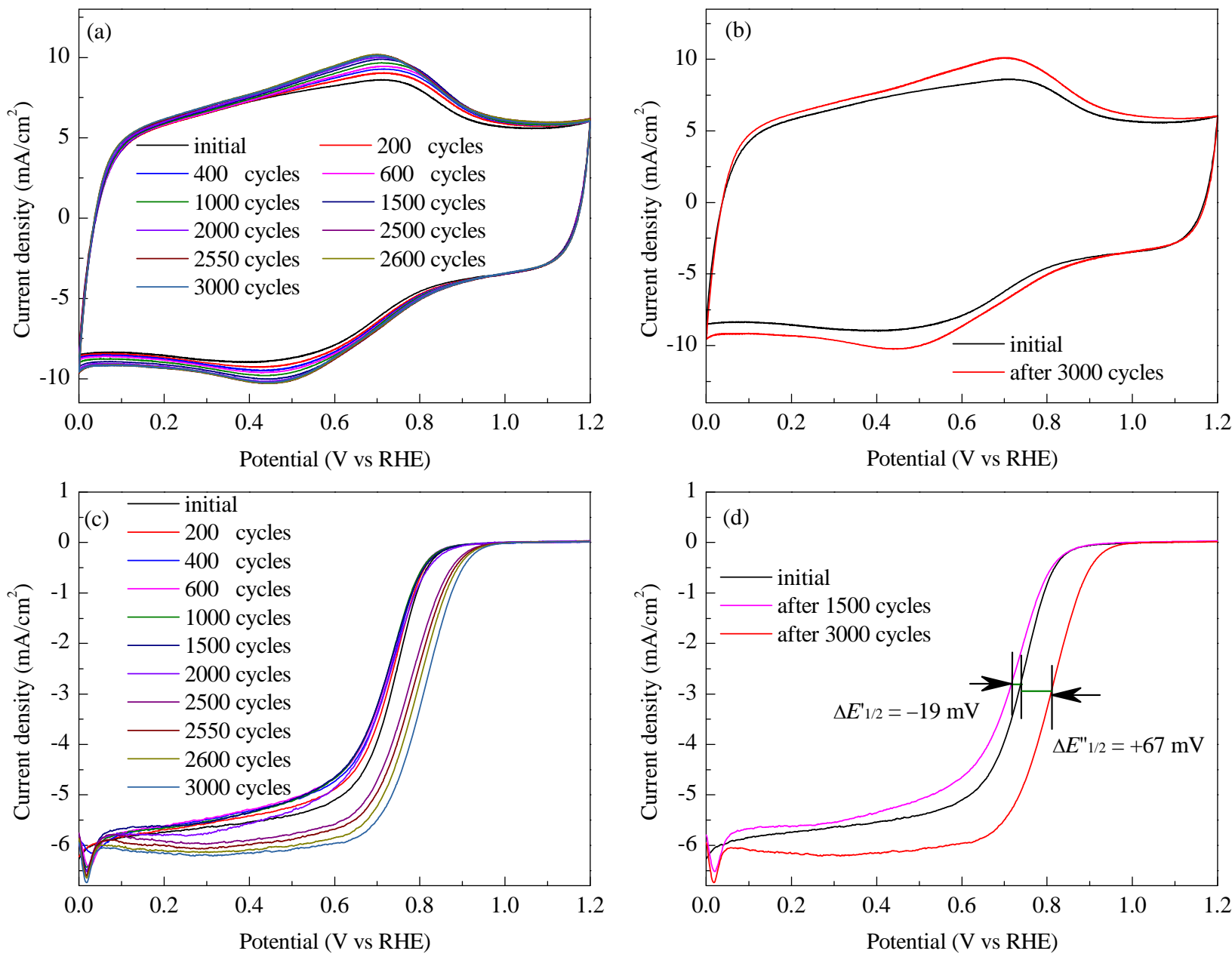

Fig. 2. $\mathrm{CV}(\mathrm{a}, \mathrm{b})$ and ORR polarization (c, d) curves of the in-house-made NPME measured in $\mathrm{N}_{2}$-saturated and $\mathrm{O}_{2}$-saturated electrolyte during ADT experiments. Potential cycling was carried out between 0.6 and $1.2 \mathrm{~V}$ (vs RHE) in $\mathrm{O}_{2}$-saturated $0.1 \mathrm{~mol} / \mathrm{L} \mathrm{HClO} 4$ at a scan rate of $100 \mathrm{mV} / \mathrm{s}$. 

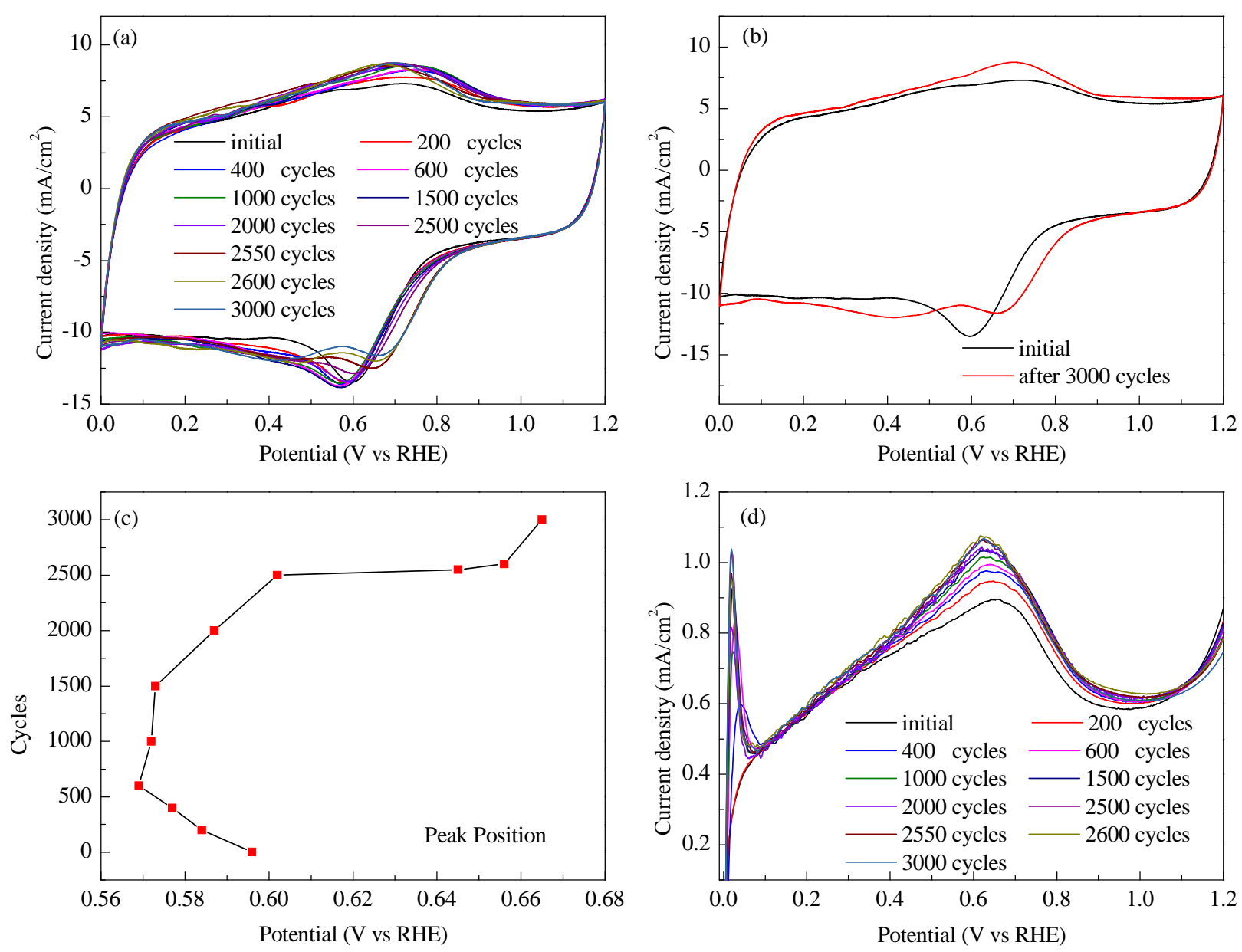

Fig. 4. (a) CV curves of the in-house-made NPME measured in $\mathrm{O}_{2}$-saturated electrolyte at selected ADT cycle numbers; (b) CV curves recorded in $\mathrm{O}_{2}$-saturated electrolyte before and after the ADT experiments; (c) Position of the oxide reduction peak at the different cycle numbers in (a); (d) Linear sweep voltammetry (LSV) curves of the in-house-made NPME collected in $\mathrm{N}_{2}$-saturated electrolyte during the ADT experiments. Potential cycling was carried out between 0.6 and $1.2 \mathrm{~V}$ (vs RHE) in $\mathrm{O}_{2}$-saturated $0.1 \mathrm{~mol} / \mathrm{L} \mathrm{HClO}_{4}$ at a scan rate of $100 \mathrm{mV} / \mathrm{s}$.

to a higher potential. Two peaks appeared in the CV curve measured after the ADT experiment (Fig. 4(b)). One peak was negatively shifted and the other was positively shifted compared with the position of the oxide reduction peak observed before the ADT (Fig. 4(a)). These two peaks might be correlated to different types of active site. We speculate that the negatively shifted peak may have arisen from degraded NPME active sites, while the positively shifted peak may be attributable to uncertain generated active sites. To further our understanding, the background capacitive current was measured in $\mathrm{N}_{2}$-saturated electrolyte at a scan rate of $10 \mathrm{mV} / \mathrm{s}$ (Fig. 4(d)). At the beginning, no peaks were observed between 0-0.1 V. After 400 potential cycles, an apparent peak appeared in this potential range and continuously evolved with increasing potential cycle number from 400 to 3000 . It is worth pointing out that a peak in the potential range of $0-0.1 \mathrm{~V}$ generally corresponds to $\mathrm{H}_{2}$ desorption [39], and so may have originated from generated active sites.

As the potential cycle number was increased from 3000 to 8000 , the shift in the position of the oxide reduction peak in the $\mathrm{CV}$ curves and the change in the current density at $0.75 \mathrm{~V}$ (vs
RHE) in the ORR curves agreed well with those observed in the first 3000 potential cycles (Fig. 5). Many more potential cycles led to a higher and higher ORR activity. This was attributable to possible new active sites that continuously built up on the NPME. After 8000 potential cycles between 0.6-1.2 V (vs RHE) in $\mathrm{O}_{2}$-saturated electrolyte, the NPME showed an identical ORR polarization curve to that observed for the commercial $\mathrm{Pt} / \mathrm{C}$ before the ADT experiment (Fig. 6).

To identify the nature of the active sites possibly generated during the ADT, the electrocatalyst samples were analyzed with TEM. Before the ADT, the in-house-made NPME contained no particles (Fig. 7(a)). However, after the ADT a few irregular nanoparticles were observed on the surface of the NPME (Fig. 7(b)). As shown in Fig. 7(c), the crystalline lattice spacing of the particles was $0.229 \mathrm{~nm}$, corresponding to the (111) plane of platinum. EDX analysis of the sample also clearly revealed the presence of Pt (Fig. 7(d)), in good agreement with the HRTEM results. It is clear that Pt nanoparticles grew on the NPME during the ADT process.

Furthermore, ORR polarization curves were measured at different RDE rotation rates to determine the electron transfer 

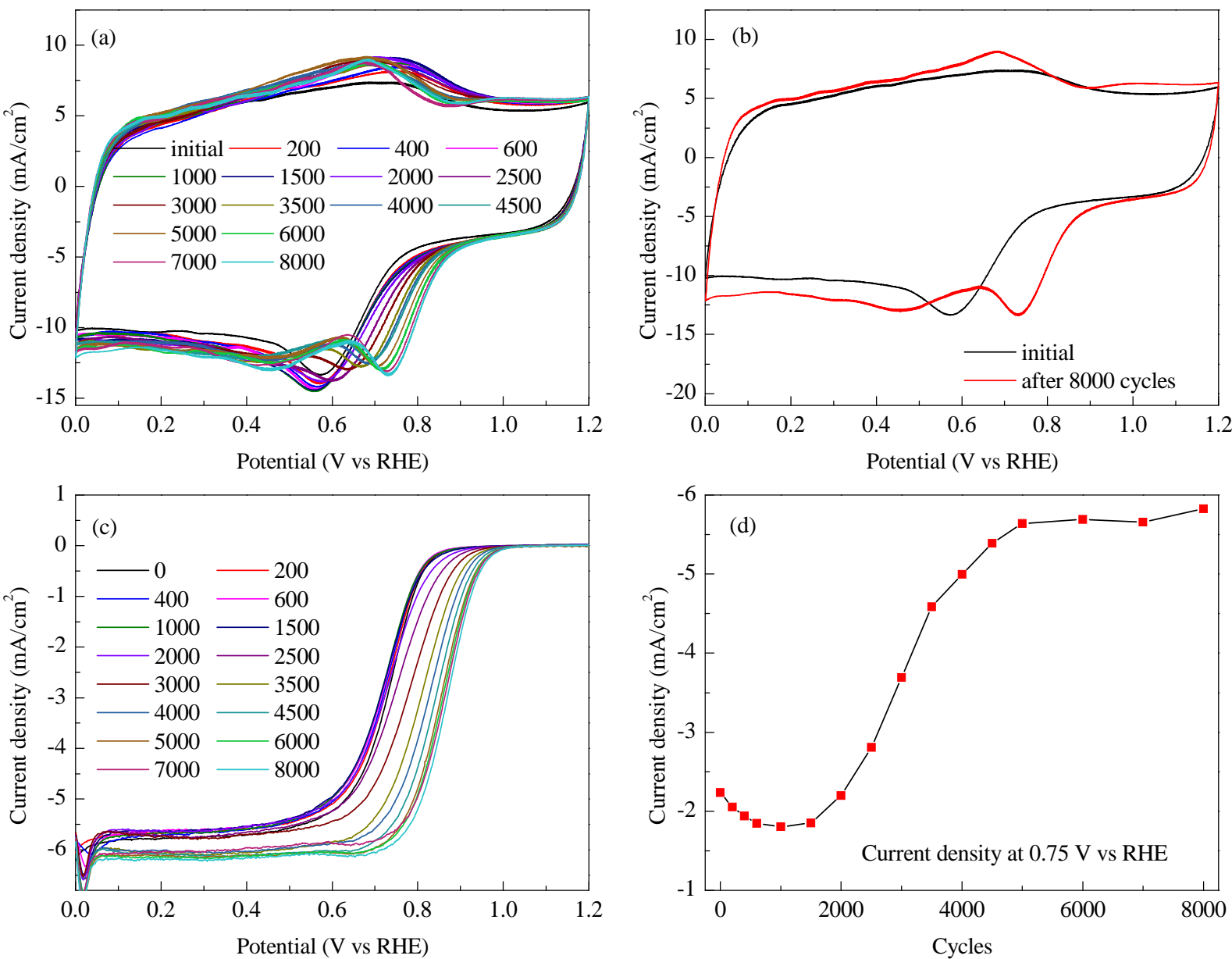

Fig. 5. (a) CV curves of the measured in $\mathrm{O}_{2}$-saturated electrolyte at different potential cycle numbers; (b) CV curves of the in-house-made NPME recorded in $\mathrm{O}_{2}$-saturated electrolyte before and after the ADT experiments; (c) ORR polarization curves; (d) Current density at $0.75 \mathrm{~V}$ (vs RHE) measured during the ADT experiments. Potential cycling was carried out between 0.6 and $1.2 \mathrm{~V}$ (vs RHE) in $\mathrm{O}_{2}$-saturated $0.1 \mathrm{~mol} / \mathrm{L} \mathrm{HClO} \mathrm{H}_{4}$ at a scan rate of 100 $\mathrm{mV} / \mathrm{s}$.

number before and after the ADT. As shown in Fig. 8(a) and (b), the electron transfer number before ADT was calculated to be 3.7, indicating that $\mathrm{H}_{2} \mathrm{O}_{2}$ formed during the ORR process. After

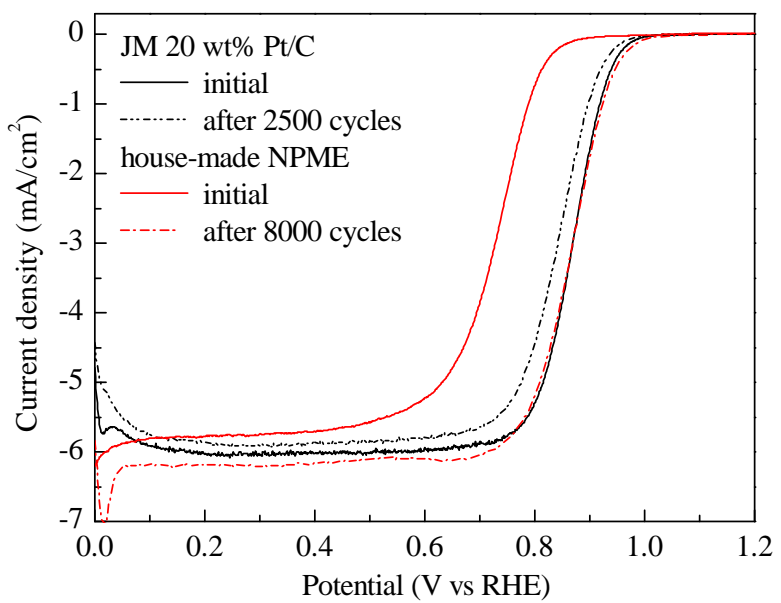

Fig. 6. ORR polarization curves of commercial $\mathrm{Pt} / \mathrm{C}$ and in-house-made NPME before and after potential cycling in $\mathrm{O}_{2}$-saturated $0.1 \mathrm{~mol} / \mathrm{L}$ $\mathrm{HClO}_{4}$. Potential cycling was carried out from 0.6 to $1.2 \mathrm{~V}$ (vs RHE) at $100 \mathrm{mV} / \mathrm{s}$. potential cycling, the electron transfer number was calculated to be 4.0 (Fig. 8(c) and (d)), which means that the electrocatalyst behaved like a typical Pt electrocatalyst with the $4 \mathrm{e}^{-} \mathrm{ORR}$ process. Therefore, the Pt nanoparticles confirmed above to have been deposited on the in-house-made NPME after the ADT led to the abnormal performance.

It is necessary to figure out the process of platinum nanoparticle deposition on the NPME during ADT in acidic medium. The degradation mechanism of Pt-based electrocatalysts has been widely studied under potential cycling conditions [40,41]. A major mechanism is Ostwald ripening via dissolution and re-deposition of Pt [42]. During the potential cycling process, $\mathrm{Pt}$ dissolution starts above $1.0 \mathrm{~V}$ (vs RHE) and drastically increases when the upper potential limit is increased above $1.2 \mathrm{~V}$ (RHE) [43]. In our case, a potential of 0.6-1.2 V (vs RHE) was applied to the working electrode. Simultaneously, the platinum counter electrode experiences an opposite electrochemical process [44]. Namely, the counter electrode functions as a cathode whenever the working electrode is operating as an anode and vice versa, which balances the reaction occurring at the working electrode. For example, in aqueous solution, if electrochemical reduction occurs at the working electrode, 

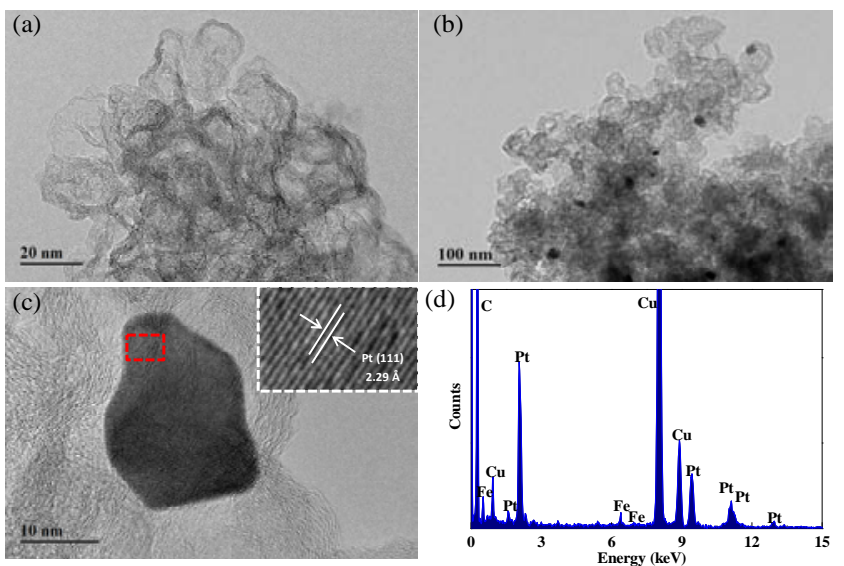

Fig. 7. TEM images of the in-house-made NPME before (a) and after (b) the ADT experiments; (c) High resolution TEM image of a nanoparticle grown on the NPME (inset is selected area diffraction pattern of the nanoparticle); (d) EDX spectrum of the nanoparticle in (c).

oxygen may evolve from the platinum counter electrode. Therefore, the dissolution and re-deposition of Pt from the counter electrode also occurs in the three-electrode electrochemical cell. This phenomenon has not been paid enough at- tention in the past, because it is generally assumed that the platinum counter electrode is inert and can be used in electrochemical tests without any issues. Actually, the Pt of the counter electrode dissolves and diffuses to the working electrode, where it is re-deposited. This process takes time, and will not affect the test until enough Pt has been deposited on the working electrode. In this scenario, the presence of deposited Pt will influence the measurement and mislead our judgment of the electrocatalyst coated on the working electrode. In our case, during the first 200 potential cycles, the amount of Pt deposited on the working electrode was low enough that its influence on the electrochemical measurement could not be observed (Fig. 4(d)). After more than 400 cycles, a sufficient amount of Pt had been deposited for its effects to become observable, which became more and more serious with increasing cycle number, which definitely should be avoided.

In the three-electrode system used for the evaluation of NPMEs, the dissolution and re-deposition of Pt from the counter electrode misleadingly enhances NPME performance during the ADT process in acidic medium. Therefore, selection of an appropriate counter electrode is vital. Besides platinum, a recent report has shown that palladium and rhodium can also dissolve during potential cycling in acidic solution [45]. There-
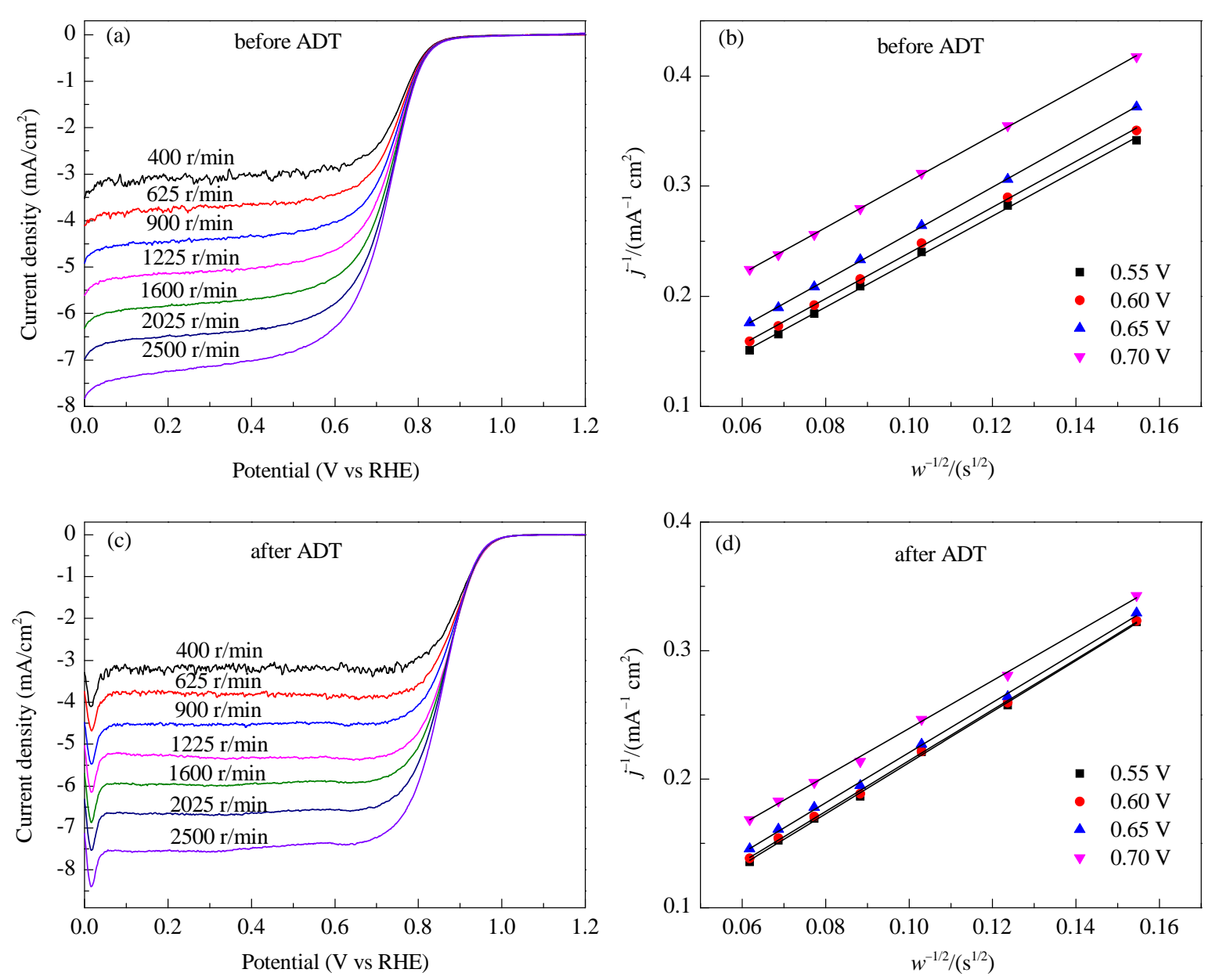

Fig. 8. ORR polarization curve of the in-house-made NPME before ADT recorded at different rotation rates in $\mathrm{O}_{2}$-saturated $0.1 \mathrm{~mol} / \mathrm{L} \mathrm{HClO}_{4}(\mathrm{a})$ and corresponding K-L plots (b); ORR polarization curve of the un-house-made NPME after ADT collected at different rotation speeds in $\mathrm{O}_{2}$-saturated 0.1 $\mathrm{mol} / \mathrm{L} \mathrm{HClO}_{4}$ (c) and corresponding K-L plots (d). 
fore, graphite was chosen as an alternative counter electrode in this study $[19,25,46]$. Other stable counter electrodes have also been used in the literature, such as glassy carbon plate [47] and gold wire [30]. ADT was performed on the in-house-made NPME under the same conditions except for the counter electrode. With the graphite counter electrode, the CV curves measured during 3000 potential cycles were similar to those collected with the Pt counter electrode (Fig. 9(a) and (b)). However, the ORR polarization curve continuously negatively shifted with cycle number. After the ADT process, the half-wave potential had negatively shifted by about $31 \mathrm{mV}$, without any positive shift (Fig. 9(c) and (d)). In terms of the current density at $0.75 \mathrm{~V}$ during the ADT (Fig. 10), at less than 1000 cycles, the current density was the same no matter which counter electrode was used. However, when the potential cycle number was greater than 1000 , the current density measured with the platinum counter electrode became higher than that with the graphite counter electrode. This result and the polarization curves measured in $\mathrm{N}_{2}$-saturated electrolyte (Fig. 4) further confirmed that Pt dissolved from the Pt counter electrode and deposited on the working electrode. When the potential cycle number was lower than 200, only a small amount of Pt had deposited on the working electrode and so no characteristic $\mathrm{H}_{2}$ desorption peak appeared. When the potential cycle number

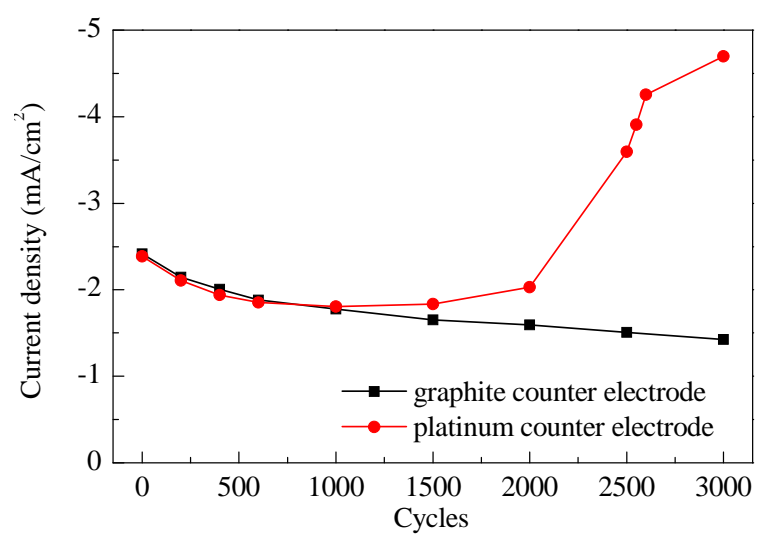

Fig. 10. Current density at $0.75 \mathrm{~V}$ (vs RHE) for the ORR polarization curves of the in-house-made NPME during ADT with platinum and graphite counter electrode. Potential cycling was carried out in $\mathrm{O}_{2}$-saturated $0.1 \mathrm{~mol} / \mathrm{L} \mathrm{HClO}_{4}$ from 0.6 to $1.2 \mathrm{~V}$ (vs RHE) at $100 \mathrm{mV} / \mathrm{s}$.

was greater than 400, the much larger amount of deposited Pt led to the appearance of the $\mathrm{H}_{2}$ desorption peak. However, the deposited Pt did appear to have an effect on the ORR performance, possibly because of its small size [48]. Further increasing the potential cycle number allowed the deposited Pt nanoparticles to grow larger. When the potential cycle number was
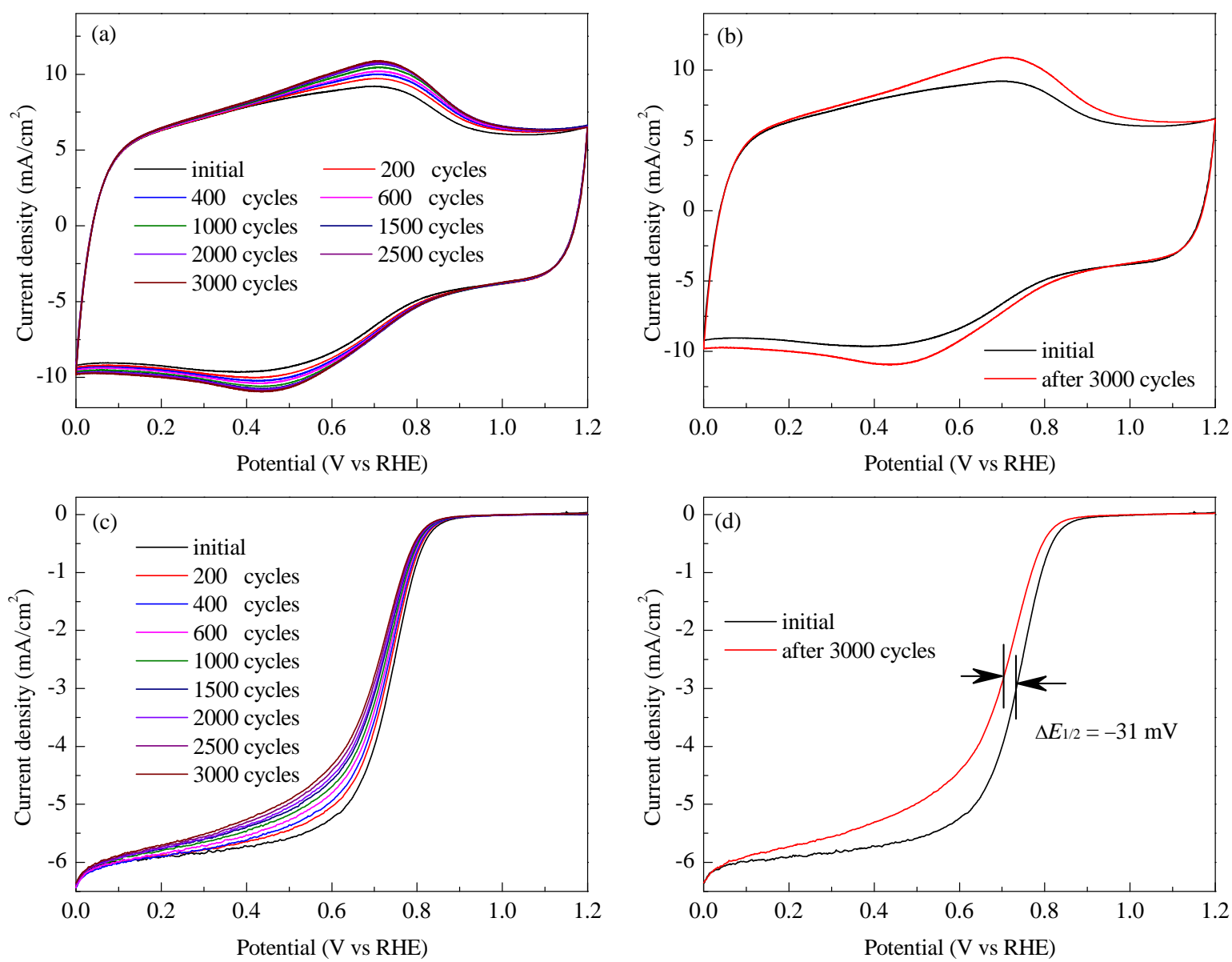

Fig. 9. CV curves $(\mathrm{a}, \mathrm{b})$ and ORR polarization curves $(\mathrm{c}, \mathrm{d})$ of the in-house-made NPME collected in $\mathrm{N}_{2}$ - and $\mathrm{O}_{2}$-saturated electrolyte, respectively. Potential cycling was carried out between 0.6 and $1.2 \mathrm{~V}$ (vs RHE) in $\mathrm{O}_{2}$-saturated 0.1 mol/L $\mathrm{HClO}_{4}$ using a graphitic rod as the counter electrode and a scan rate of $100 \mathrm{mV} / \mathrm{s}$. 
greater than 1000, the deposited Pt nanoparticles had an obvious effect, enhancing the ORR performance of the in-housemade NPME.

\section{Conclusions}

The ADT has been widely used to evaluate the durability of electrocatalysts under harsh conditions in the standard three-electrode electrochemical cell. In the case of the assessment of NPMEs, the type of counter electrode will impact the apparent durability of the electrocatalyst in acidic medium. When platinum is used as the counter electrode, the Pt dissolves in the electrolyte during potential cycling and diffuses to the working electrode, where it is re-deposited on the NPME. With increasing potential cycle number, the deposited Pt grows larger and larger and significantly enhances the ORR on the NPME. This phenomenon causes NPMEs to exhibit abnormally high performance during ADT under these conditions. In contrast, when graphite is used as the counter electrode, the ADT experiment will not be affected by the counter electrode. This study demonstrates that platinum counter electrodes should be avoided when evaluating NPMEs using ADT experiments in acidic media.

\section{References}

[1] O. J. Curnick, B. G. Pollet, P. M. Mendes, RSC $A d v$., 2012, 2, 8368-8374.

[2] V. R. Stamenkovic, B. S. Mun, M. Arenz, K. J. Mayrhofer, C. A. Lucas, G. Wang, P. N. Ross, N. M. Markovic, Nat. Mater., 2007, 6, 241-247.

[3] Y. Garsany, I. L. Singer, K. E. Swider-Lyons, J. Electroanal. Chem., 2011, 662, 396-406.

[4] U. A. Paulus, T. J. Schmidt, H. A. Gasteiger, R. J. Behm, J. Electroanal. Chem., 2001, 495, 134-145.

[5] K. J. J. Mayrhofer, D. Strmcnik, B. B. Blizanac, V. Stamenkovic, M. Arenz, N. M. Markovic, Electrochim. Acta, 2008, 53, 3181-3188.

[6] G. Yannick, O. A. Baturina, K. E. Swider-Lyons, S. S. Kocha, Anal. Chem., 2010, 82, 6321-6328.

[7] Y. Garsany, A. Epshteyn, A. P. Purdy, K. L. More, K. E. Swider-Lyons, J Phys. Chem. Lett., 2010, 1, 1977-1981.
[8] C. Chen, Y. J. Kang, Z. Y. Huo, Z. W. Zhu, W. Y. Huang, H. L. Xin, J. D. Snyder, D. Li, J. A. Herron, M. Mavrikakis, M. Chi, K. L. More, Y. D. Li, N. M. Markovic, G. A. Somorjai, P. Yang, V. R. Stamenkovic, Science, 2014, 343, 1339-1343.

[9] C. H. Cui, L. Gan, M. Heggen, S. Rudi, P. Strasser, Nat. Mater., 2013, $12,765-771$.

[10] H. A. Gasteiger, S. S. Kocha, B. Sompalli, F. T. Wagner, Appl. Catal. B, 2005, 56, 9-35.

[11] Z. W. Chen, D. Higgins, A. P. Yu, L. Zhang, J. J. Zhang, Energy Environ. Sci., 2011, 4, 3167-3192.

[12] L. J. Yang, Y. Zhao, S. Chen, Q. Wu, X. Z. Wang, Z. Hu, Chin. J. Catal., 2013, 34, 1986-1991.

[13] M. H. Shao, Q. W. Chang, J. P. Dodelet, R. Chenitz, Chem. Rev., 2016, 116, 3594-3657.

[14] W. J. Jiang, L. Gu, L. Li, Y. Zhang, X. Zhang, L. J. Zhang, J. Q. Wang, J. S. Hu, Z. Wei, L. J. Wan, J. Am. Chem. Soc., 2016, 138, 3570-3578.

[15] G. P. Wu, J. Wang, W. Ding, Y. Nie, L. Li, X. Q. Qi, S. G. Chen, Z. D. Wei, Angew. Chem. Int. Ed., 2016, 55, 1340-1344.

[16] R. Wu, S. G. Chen, Y. L. Zhang, Y. Wang, Y. Nie, W. Ding, X. Q. Qi, Z. D. Wei, J. Mater. Chem. A, 2016, 4, 2433-2437.

[17] W. Ding, L. Li, K. Xiong, Y. Wang, W. Li, Y. Nie, S. G. Chen, X. Q. Qi, Z. D. Wei, J. Am. Chem. Soc., 2015, 137, 5414-5420.

[18] Z. H. Xiang, Y. H. Xue, D. P. Cao, L. Huang, J. F. Chen, L. M. Dai, Angew. Chem. Int. Ed., 2014, 53, 2433-2437.

[19] Q. Wang, Z. Y. Zhou, Y. J. Lai, Y. You, J. G. Liu, X. L. Wu, E. Terefe, C. Chen, L. Song, M. Rauf, N. Tian, S. Q. Sun, J. Am. Chem. Soc., 2014, 136, 10882-10885.

[20] H. W. Liang, X. D. Zhuang, S. Brüller, X. L. Feng, K. Müllen, Nat. Commun., 2014, 5, 4973.

[21] Y. Hu, J. O. Jensen, W. Zhang, L. N. Cleemann, W. Xing, N. J. Bjerrum, Q. Li, Angew. Chem. Int. Ed., 2014, 53, 3675-3679.

[22] H. T. Chung, J. H. Won, P. Zelenay, Nat. Commun., 2013, 4, 1922.

[23] H. L. Peng, Z. Y. Mo, S. J. Liao, H. G. Liang, L. J. Yang, F. Luo, H. Y. Song, Y. L. Zhong, B. Q. Zhang, Sci. Rep., 2013, 3, 1765.

[24] E. Yeager, Electrochim. Acta, 1984, 1527-1537.

[25] Y. S. Zhu, B. S. Zhang, X. Liu, D. W. Wang, D. S. Su, Angew. Chem. Int. Ed., 2014, 53, 10673-10677.

[26] Y. Nie, L. Li, Z. D. Wei, Chem. Soc. Rev., 2015, 44, 2168-2201.

[27] P. Kissinger, W. R. Heineman, Laboratory Techniques in Electroanalytical Chemistry, Revised and Expanded, CRC Press, 1996.

[28] A. J. Bard, L. R. Faulkner, Electrochemical Methods: Fundamentals and Applications, 2nd Edition, Wiley \& Sons, 2001.

[29] Z. Wu, L. Chen, J. Liu, K. Parvez, H. Liang, J. Shu, H. Sachdev, R. Graf,

\section{Graphical Abstract}

Chin. J. Catal., 2016, 37: 1109-1118 doi: 10.1016/S1872-2067(16)62454-3

Influence of counter electrode material during accelerated durability test of non-precious metal electrocatalysts in acidic medium

Jia Li, Huiyuan Liu, Yang Lü, Xinwen Guo, Yujiang Song*

Dalian University of Technology;

Dalian Institute of Chemical Physics, Chinese Academy of Sciences

Graphite rather than platinum should be used as the counter electrode for the evaluation of non-precious metal electrocatalysts using accelerated durability tests in acidic media, because Pt dissolves and deposits on the electrocatalyst, affecting the assessment.

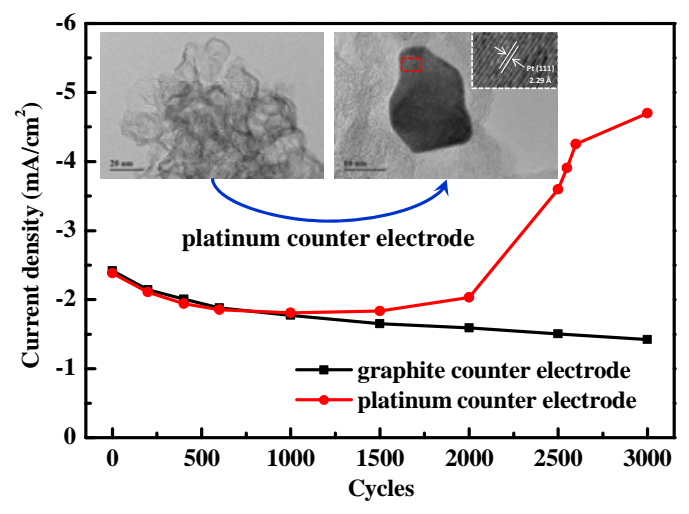


X. Feng, K. Muellen, Adv. Mater., 2014, 26, 1450-1455.

[30] S. Yuan, J. Shui, L. Grabstanowicz, C. Chen, S. Commet, B. Reprogle, T. Xu, L. Yu, D. J. Liu, Angew. Chem. Int. Ed., 2013, 52, 8349-8353.

[31] J. S. Jirkovský, M. Halasa, D. J. Schiffrin, Phys. Chem. Chem. Phys., 2010, 12, 8042-8053.

[32] H. R. Colón-Mercado, H. Kim, B. N. Popov, Electrochem. Commun., 2004, 6, 795-799.

[33] T. J. Kim, G. Kwon, Y. T. Kim, Chem. Commun., 2013, 50, 596-598.

[34] S. S. Li, H. Y. Liu, Y. Wang, W. Xu, J. Li, Y. Liu, X. W. Guo, Y. J. Song, RSC Adv., 2015, 5, 8787-8792.

[35] J. Li, Y. Xie, S. S. Li, Y. Z. Bai, X. W. Guo, B. L. Yi, Y. J. Song, Mater. Res. Express, 2014, 1, 025045.

[36] Y. Xie, H. Q. Li, C. Z. Tang, S. S. Li, J. Li, Y. Lv, X. M. Wei, Y. J. Song, J. Mater. Chem. A, 2014, 2, 1631-1635.

[37] R. Borup, J. Meyers, B. Pivovar, Y. S. Kim, R. Mukundan, N. Garland, D. Myers, M. Wilson, F. Garzon, D. Wood, P. Zelenay, K. More, K. Stroh, T. Zawodzinski, J. Boncella, J. E. McGrath, M. Inaba, K. Miyatake, M. Hori, K. Ota, Z. Ogumi, S. Miyata, A. Nishikata, Z. Siroma, Y. Uchimoto, K. Yasuda, K.-i. Kimijima, N. Iwashita, Chem. Rev., 2007, 107, 3904-3951.

[38] D. Singh, J. Tian, K. Mamtani, J. King, J. T. Miller, U. S. Ozkan, J.
Catal., 2014, 317, 30-43.

[39] W. Vielstich, Cyclic Voltammetry, John Wiley \& Sons, Ltd, 2010.

[40] J. Xie, D. L. Wood, K. L. More, P. Atanassov, R. L. Borup, J. Electrochem. Soc., 2005, 152, A1011-A1020.

[41] P. J. Ferreira, G. J. la O', Y. Shao-Horn, D. Morgan, R. Makharia, S. Kocha, H. A. Gasteiger, J. Electrochem. Soc., 2005, 152, A2256-A2271.

[42] Y. Shao-Horn, W. C. Sheng, S. Chen, P. J. Ferreira, E. F. Holby, D. Morgan, Top Catal., 2007, 46, 285-305.

[43] Y. Sugawara, A. P. Yadav, A. Nishikata, T. Tsuru, ECS Trans., 2009, $16,117-123$.

[44] P. Vanýsek, H. Tavassol, K. L. Pilson, ECS Meeting Abstracts, 2013, MA2013-02, 2684.

[45] D. A. J. Rand, R. Woods, J. Electroanal. Chem. Interfacial Electrochem., 1972, 35, 209-218.

[46] A. Zitolo, V. Goellner, V. Armel, M. T. Sougrati, T. Mineva, L. Stievano, E. Fonda, F. Jaouen, Nat. Mater., 2015, 14, 937-942.

[47] Y. C. Wang, Y. J. Lai, L. Song, Z. Y. Zhou, J. G. Liu, Q. Wang, X. D. Yang, C. Chen, W. Shi, Y. P. Zheng, M. Rauf, S. G. Sun, Angew. Chem. Int. Ed., 2015, 54, 9907-9910.

[48] K. Kinoshita, J. Electrochem. Soc., 1990, 137, 845-848.

\title{
对电极材料对非贵金属电催化剂耐久性评价的影响
}

\author{
李 佳 ${ }^{\mathrm{a}}$, 刘会园 ${ }^{\mathrm{b}}$, 吕 洋 $^{\mathrm{a}}$, 郭新闻 ${ }^{\mathrm{a}}$, 宋玉江 ${ }^{\mathrm{a},{ }^{*}}$ \\ a 大连理工大学化工学院, 精细化工国家重点实验室, 辽宁大连 116024 \\ b中国科学院大连化学物理研究所, 洁净能源国家实验室 (筹), 辽宁大连 116023
}

摘要: 质子交换膜燃料电池 (PEMFCs) 环境友好, 具有高的能量转换效率, 已受到了广泛的关注. 目前, 铂基电催化剂广泛 使用在 PEMFCs 中, 但铂的储量有限, 活性低, 耐久性差, 成本高, 急需开发高性能的非贵金属电催化剂替代铂基电催化剂. 非贵金属电催化剂的电化学表征基本上都沿用了铂基电催化剂的评价体系和方法, 不一定适用于非贵金属电催化剂的表 征.

本文选用铂和石墨为对电极考察其对非贵金属电催化剂在酸性电解质中耐久性测试的影响. 当使用铂对电极时, 商业 $\mathrm{Pt} / \mathrm{C}$ 电催化剂的氧还原 (ORR) 活性随着耐久性测试圈数的增加而降低, 而非贵金属电催化剂的氧还原活性在耐久性测试 过程中的变化规律与商业 $\mathrm{Pt} / \mathrm{C}$ 不同, 呈现先降低, 后升高的规律. 耐久性测试前后的透射电镜 (TEM) 分析表明非贵金属 电催化剂经过耐久性测试后, 在电催化剂表面生长了铂纳米颗粒. 高分辨透射电镜 (HRTEM) 和能量色散 X 射线光谱 (EDX) 进一步证明以铂为对电极的三电极体系, 在进行非贵金属电催化剂耐久性测试的过程中, 非贵金属电催化剂表面生 长了铂纳米颗粒, 使得非贵金属电催化剂的 ORR 活性在耐久性测试后得到显著提高. 耐久性测试前后, 非贵金属电催化 剂氧还原过程的电子转移数由 3.7 变为 4.0 , 再次证明了耐久性测试过程中铂颗粒的生成. 在三电极电化学体系中, 当工作 电极发生阴极反应时, 对电极为阳极反应, 反之亦然, 即在工作电极上发生的任何电化学过程, 都会在对电极上完成相反的 电化学过程. 在循环电位扫描过程中, 当铂对电极的电压高于 $1.0 \mathrm{~V}$ (vs RHE) 时, 开始发生铂的溶解现象, 并且当电压高于 $1.2 \mathrm{~V}$ (vs RHE) 时, 铂的溶解量会急剧增加, 部分溶解的铂会扩散到工作电极附近, 并在工作电极的非贵金属电催化剂表 面发生沉积作用. 随着扫描圈数的增加, 沉积的铂纳米颗粒的数量增加, 颗粒变大, 从而使非贵金属电催化剂的表观 ORR 活性显著提高. 该现象使得非贵金属电催化剂在酸性电解质中无法表现出其真实的耐久性. 当选用石墨棒为对电极材料 时, 非贵金属电催化剂在酸性电解质中的 ORR 活性不会受到对电极材料的影响.

通过考察对电极材料对非贵金属电催化剂在酸性电解质中耐久性能的影响, 可以得出结论, 即对非贵金属电催化剂在 酸性电解质中的耐久性测试中, 不宜使用铂对电极, 应该使用石墨为对电极材料, 以防止对电极材料干扰耐久性测试. 关键词: 非贵金属电催化剂; 铂对电极; 石墨对电极; 加速老化测试; 酸性电解质

收稿日期: 2016-01-30. 接受日期: 2016-05-07. 出版日期: 2016-07-05.

*通讯联系人. 电话/传真: (0411) 84986485; 电子信箱: yjsong@dlut.edu.cn

基金来源：大连理工大学基本科研业务费专项资金 (DUT15RC(3)001, DUT15ZD225); 辽宁省高等学校优秀科技人才支持计划 (LR2015014); 辽宁省百千万人才工程 (辽百千万立项[2015]19 号); 大连市杰出青年科技人才 (2015R006).

本文的英文电子版由Elsevier出版社在ScienceDirect上出版(http://www.sciencedirect.com/science/journal/18722067). 